\title{
Accurate quantification of modified cyclic peptides without the need for authentic standards.
}

\author{
Rosemary I. Adaba ${ }^{\mathrm{a}}$, Greg Mann ${ }^{\mathrm{b}}$, Andrea Raab ${ }^{\mathrm{c}}$, Wael E. Houssen ${ }^{\mathrm{a}, \mathrm{d}, \mathrm{e}}$, Andrew R. McEwan ${ }^{\mathrm{a}, \mathrm{d}}$, Louise \\ Thomas $^{\text {a,d }}$, Jioji Tabudravu ${ }^{\mathrm{a}}$, James H. Naismith ${ }^{\mathrm{b}}$ and Marcel Jaspars*a.
}

\author{
${ }^{a}$ Marine Biodiscovery Centre, Department of Chemistry, University of Aberdeen, Meston Walk, Aberdeen. AB24 $3 U E$, UK \\ ${ }^{b}$ Biomedical Sciences Research Complex, University of St Andrews, North Haugh, St Andrews, Fife KY16 9ST, UK \\ ${ }^{c}$ TESLA, Department of Chemistry, University of Aberdeen, UK \\ ${ }^{d}$ Institute of Medical Sciences, University of Aberdeen, Aberdeen AB25 2ZD, UK \\ 'Pharmacognosy Department, Faculty of Pharmacy, Mansoura University, Mansoura 35516, Egypt.
}

\section{ARTICLE INFO}

\section{ABSTRACT}

\section{Article history:}

Received

Received in revised form

Accepted

Available online

Keywords:

Cyclic peptide

LC-MS

ICP-MS

NMR

Quantification without authentic standards

Cyanobacteria

qNMR

\begin{abstract}
There is a growing interest in the use of cyclic peptides as therapeutics, but their efficient production is often the bottleneck in taking them forward in the development pipeline. We have recently developed a method to synthesise azole-containing cyclic peptides using enzymes derived from different cyanobactin biosynthetic pathways. Accurate quantification is crucial for calculation of the reaction yield and for the downstream biological testing of the products. In this study, we demonstrate the development and validation of two methods to accurately quantify these compounds in the reaction mixture and after purification. The first method involves the use of a HPLC coupled in parallel to an ESMS and an ICPMS, hence correlating the calculated sulfur content to the amount of cyclic peptide. The second method is an NMR ERETIC method for quantifying the solution concentration of cyclic peptides. These methods make the quantification of new compounds much easier as there is no need for the use of authentic standards when they are not available.
\end{abstract}

2016 Elsevier Ltd. All rights reserved.

\section{Introduction}

The growing application of peptides in drug discovery necessitates their accurate quantification in order to obtain the right metabolic, enzymatic, kinetic and pharmacokinetic data. ${ }^{1-6}$ Several methods for peptide quantification have been reported to date, these include liquid chromatography combined with ultraviolet (UV) or fluorescence detection, capillary electrophoresis with UV detection, matrix-assisted laserdesorption/ionization mass spectrometry (MALDI-MS), surfaceenhanced laser desorption/ionization (SELDI), ${ }^{6-12}$ liquid chromatography- mass spectrometry (LC-MS), ${ }^{7,8}$ inductively coupled plasma mass spectrometry (ICP-MS) $)^{13-14}$ and quantitative nuclear magnetic resonance (qNMR). ${ }^{9}$

Limitations of these techniques for quantification of peptides vary by technique. Matrix effects limit optical techniques such as UV and fluorescence detection. ${ }^{7,8}$ Different mass spectrometric methods suffer from different problems. Matrix-assisted laser desorption/ionization-time of flight mass spectrometry (MALDITOF) and electrospray ionisation (ESMS) techniques both suffer drawbacks such as differential response of proteins and peptides depending on size, hydrophobicity, matrix, or solvents. ${ }^{10}$ At low mass resolution, LC-MS data has a limited accuracy for reported intensity of the extracted ion currents due to contamination by nearby peptide signals, thereby affecting accurate quantification. ${ }^{11,12}$ For quantification purposes, it is necessary to address these issues in particular ionisation efficiency and matrix effects when using an ESMS or MALDI-MS direct measurements. For this reason various sample treatments for MS-based quantification are reported in the literature for peptides including; isotope-coded affinity tag reagents (ICATs), ${ }^{13-15}$ isotope-coded protein labelling (ICPL), ${ }^{16-18}$ stable isotope labelling by amino acid in cell culture (SILAC), ${ }^{19-21}$ isotope-differentiated binding energy shift tag (IDBEST), chemical labelling, isobaric tagging (iTRAQ, $\mathrm{TMT}),{ }^{22,23}$ and absolute quantification with the use of synthetic

\footnotetext{
* Corresponding author: Marine Biodiscovery Centre, Department of Chemistry, University of Aberdeen, Meston Walk, Aberdeen. AB24 3UE, UK

E-mail: m.jaspars@abdn.ac.uk
} 
labelled peptides (AQUA), ${ }^{24,25}$ These methods require additional sample preparation and cost.

ICP-MS is a sensitive analytical tool for elemental analysis with advantages of having species independence and high ionization efficiency for most elements in the periodic table, high sensitivity of parts per billion to parts per trillion levels, together with affordable isotope distribution information. ${ }^{26-27}$ For these reasons it has become a significant and complementary technique in bioanalysis for the determination of biomolecules and quantification of therapeutic agents. ${ }^{28-36}$ Application of ICPMS allows the quantification of elements independent of their molecular form, hence the analyte retains its original form during quantification. Coupled with molecular information obtained from ESI-MS or MALDI enables the compound identification simultaneously with its quantification. Sulphur has been successfully used for the quantification of proteins and peptide in biological samples by coupling the ICP-MS to different chromatographic systems. ${ }^{37-40}$

NMR produces a signal for any species that will have an area that is proportional to its concentration. ${ }^{40}$ Complex mixtures can be analyzed by NMR which provides the concentration of the chemical components in a mixture, hence allowing quantification of species for metabolomic and related studies. ${ }^{4-42}$ Proton NMR quantification (qNMR) by ERETIC is a non-destructive and rapid way of providing accurate analyte concentrations ${ }^{43}$ by using an indirect internal reference signal that represents a known concentration. This averts the need to determine a compoundspecific response factor, ${ }^{44}$ making qNMR an accurate and straightforward technique for quantification. The drawbacks to this method are that it requires relatively pure samples of large size that would allow sufficient signal to noise ratio $(>150: 1)^{9}$ and an internal certified reference material.

Cyclic peptides show promise in many therapeutic areas, particularly in complex diseases such as auto-immune disorders. ${ }^{45}$ Cyanobactins are a family of modified cyclic peptides that have interesting structural features including heterocycles, epimerized stereocentres and prenylated residues (Figure 1). ${ }^{46}$ Some of these modifications lead to better target affinity by constraining conformational flexibility, while others increase cellular permeability. ${ }^{47,48}$ Members of cyanobactins are known to reverse multi drug resistance in human lymphoblasts by inhibiting the Pglycoprotein (Pgp) drug efflux pump. ${ }^{49-51}$


Figure 1: Structures of some modified cyclic peptides in the cyanobactin family showing heterocycles, epimerized stereocentres and prenylated residues in trunkamide $\mathrm{A}$.

Patellamides are the most studied members of the cyanobactins. They were originally isolated from extracts of the Indo-Pacific ascidian Lissoclinum patella, but shown later to be produced by its cyanobacterial symbiont Prochloron sp.. ${ }^{52,53}$ Genomic studies of Prochloron sp. delineated the gene cluster for the biosynthesis that directs the production of the patellamides. ${ }^{54-59}$ Their biosynthesis occurs via the production of a ribosomally encoded precursor peptide, in which a core peptide sequence is modified by a series of processing enzymes. ${ }^{52,60-64} \mathrm{We}$ recently used these enzymes in vitro to generate natural and non-natural cyanobactins in milligram quantities. ${ }^{61}$ Accurate quantification of the reaction products is essential to calculate yields before and after purification and for their downstream biological screening but is challenging due to the lack of authentic standards.

To overcome this, we herein report two quantification methods, the first relies on the quantification of the sulfur content in the products to estimate the concentration of these new heterocycle containing cyclic peptides in solutions, by coupling molecular electrospray mass spectrometry (ESIMS) and elemental inductively coupled plasma mass spectrometry (ICPMS) to a high pressure liquid chromatograph (HPLC) in parallel. ${ }^{65}$ Using this approach we quantified sulfur containing peptides obtained after extraction and purification of these compounds from chemoenzymatic reaction mixtures and identified the most efficient extraction and purification strategy. While the second method describes an alternative quantification method using NMR and an ERETIC (electronic reference to access in vivo concentrations) reference for the quantification of non- sulfur containing cyclic peptides. ERETIC qNMR enabled us to obtain the concentration and identity of these new compounds simultaneously.

\section{Results and Discussion}

\subsection{Verification of sulfur quantification by HPLC}

Two sulfur containing compounds $\mathbf{1}$ and $\mathbf{2}$ (Table 1, SI Scheme 1) were used as calibration standards. The accuracy of the method 
was verified using, a known drug molecule containing sulfur; methylthioninium chloride $\mathbf{3}$, commercially available sulfate standard solution and three certified reference materials (CRMs): RM8415 (whole egg powder); BCR-062 (olive leaves) and seronorm (trace elements in urine blank) whose total sulfur contents are known were analysed. The detection limits for sulfur by HPLC ranged from 1.00 to $2.03 \times 10^{-4} \mathrm{mg} / \mathrm{mL}$ using either compound 1 or $\mathbf{2}$ as standard, with a correlation coefficient $>0.99$. There was no statistically significant difference in the results using either compound $\mathbf{1}$ or $\mathbf{2}$ for quantification of sulfur in the samples. Recovery of sulfur in the three certified reference materials was $101 \pm 8 \%$ and compound 3 was $78 \pm 2 \%$ (Table 2). The sulfur content of the HPLC calibration standards ( $\mathbf{1}$ and $\mathbf{2}$ ) was within the calculated range $( \pm 3 \%)$ allowing their use as standards in HPLCICPMS/ESMS.

Table 1: Names of compounds studied with their molecular formula and molecular masses in $\mathrm{g} / \mathrm{mol}$.

\begin{tabular}{|c|c|c|}
\hline NAME/SEQUENCE & $\begin{array}{l}\text { MOLECULAR } \\
\text { FORMULA }\end{array}$ & $\begin{array}{l}\text { MASS } \\
(\mathrm{g} / \mathrm{mol})\end{array}$ \\
\hline Cysteine (1) & $\mathrm{C}_{3} \mathrm{H}_{7} \mathrm{NO}_{2} \mathrm{~S}$ & 121.16 \\
\hline $\mathrm{N}$-acetyl cysteine (2) & $\mathrm{C}_{5} \mathrm{H}_{9} \mathrm{NO}_{3} \mathrm{~S}$ & 163.19 \\
\hline Methylthioninium chloride (3) & $\mathrm{C}_{16} \mathrm{H}_{18} \mathrm{ClN}_{3} \mathrm{~S}$ & 319.85 \\
\hline Patellamide D (4) & $\mathrm{C}_{38} \mathrm{H}_{48} \mathrm{~N}_{8} \mathrm{O}_{6} \mathrm{~S}_{2}$ & 776.97 \\
\hline Ascidiacyamide (5) & $\mathrm{C}_{36} \mathrm{H}_{52} \mathrm{~N}_{8} \mathrm{O}_{6} \mathrm{~S}_{2}$ & 756.98 \\
\hline Cyclo[IFTV(ThH)I(ThH)V(ThH)] (6) ${ }^{a}$ & $\mathrm{C}_{44} \mathrm{H}_{65} \mathrm{~N}_{9} \mathrm{O}_{7} \mathrm{~S}_{3}$ & 928.24 \\
\hline $\operatorname{Cyclo}[\operatorname{ITM}(\mathrm{ThH}) \operatorname{ITM}(\mathrm{ThH})](7)^{\mathrm{a}}$ & $\mathrm{C}_{36} \mathrm{H}_{60} \mathrm{~N}_{8} \mathrm{O}_{8} \mathrm{~S}_{4}$ & 861.17 \\
\hline 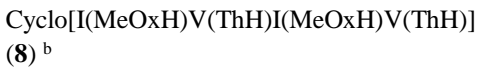 & $\mathrm{C}_{36} \mathrm{H}_{56} \mathrm{~N}_{8} \mathrm{O}_{6} \mathrm{~S}_{2}$ & 761.01 \\
\hline Cyclo[ITA(ThH)ITF(ThH)] $(\mathbf{9})^{\text {a }}$ & $\mathrm{C}_{38} \mathrm{H}_{56} \mathrm{~N}_{8} \mathrm{O}_{8} \mathrm{~S}_{2}$ & 817.03 \\
\hline Cyclo[GITA(ThH)I(ThH)V(ThH)] (10) a & $\mathrm{C}_{36} \mathrm{H}_{56} \mathrm{~N}_{8} \mathrm{O}_{7} \mathrm{~S}_{3}$ & 809.07 \\
\hline Anthranilic acid (11) & $\mathrm{C}_{7} \mathrm{H}_{7} \mathrm{NO}_{2}$ & 137.14 \\
\hline Cyclo[VGAGIGWP] $(\mathbf{1 2})^{\mathrm{c}}$ & $\mathrm{C}_{36} \mathrm{H}_{51} \mathrm{~N}_{9} \mathrm{O}_{8}$ & 737.86 \\
\hline $\begin{array}{l}\text { Cyclo[I(MeOxH)A(Thz)I(MeOxH)A(Thz)] } \\
(\mathbf{1 3})^{\mathrm{d}}\end{array}$ & $\mathrm{C}_{32} \mathrm{H}_{44} \mathrm{~N}_{8} \mathrm{O}_{6} \mathrm{~S}_{2}$ & 700.87 \\
\hline $\operatorname{Cyclo}[\mathrm{IPA}(\mathrm{Thz}) \mathrm{I}(\mathrm{MeOxH}) \mathrm{F}(\mathrm{Thz})](\mathbf{1 4})^{\mathrm{d}}$ & $\mathrm{C}_{39} \mathrm{H}_{50} \mathrm{~N}_{8} \mathrm{O}_{6} \mathrm{~S}_{2}$ & 790.32 \\
\hline Cyclo[IPA(Thz)IPFThz)] $(\mathbf{1 5})^{\mathrm{e}}$ & $\mathrm{C}_{40} \mathrm{H}_{52} \mathrm{~N}_{8} \mathrm{O}_{6} \mathrm{~S}_{2}$ & 805.02 \\
\hline Cyclo[ITA(Thz)IPF(Thz)] (16) ${ }^{\mathrm{e}}$ & $\mathrm{C}_{39} \mathrm{H}_{52} \mathrm{~N}_{8} \mathrm{O}_{7} \mathrm{~S}_{2}$ & 809.01 \\
\hline
\end{tabular}

Modified cyclic peptides prepared from the corresponding linear peptides by processing with: ${ }^{\mathrm{a}} \mathrm{TruD}$ heterocyclase, which converts Cys to thiazoline, followed by PatGmac; 'PatD heterocyclase, which converts Cys, Ser, Thr to thiazoline, oxazoline and methyl oxaxoline respectively, followed by $\mathrm{PatG}_{\mathrm{mac}}$, 'Macrocylicization by $\mathrm{PatG}_{\mathrm{mac}}$, ${ }^{\mathrm{d}}$ MicD heterocyclase, which converts Cys to thiazoline, Thr to methyl oxaxoline, followed by PatGmac, followed ArtGox and ${ }^{\mathrm{E} L y n D}$ heterocyclase, which converts Cys to thiazoline, followed by PatGmac and ArtGox.

Quantification of compound 3 gave a recovery of $75 \pm 3 \%$ (Table 2) of the theoretical value which is similar to the value achieved during total sulfur determination. This indicates that there was no loss of compound $\mathbf{3}$ on the column, that the standards used for quantification and the methods used are of sufficient accuracy.
Table 2: Sulfur quantification results for the concentration of compound $\mathbf{3}$ and certified reference materials in $\mathrm{mg}$ compound/g solution.

\begin{tabular}{ccc}
\hline $\begin{array}{c}\text { Sample } \\
(\mathbf{n}=\mathbf{3})\end{array}$ & $\begin{array}{c}\text { Theoretical } \\
\text { mg compound/g }\end{array}$ & $\begin{array}{c}\text { Found } \\
\text { mg compound/g }\end{array}$ \\
\hline $\mathbf{3}$ & 1.41 & $1.34 \pm 0.0439$ \\
Total S in CRM's & Certified Value & $\mathbf{~ m g / k g}$ \\
RM8451 & $5120 \pm 500$ & $4762 \pm 54$ \\
BCR-062 & 1600 (indicative & $1588 \pm 32$ \\
& value) & $617 \pm 123$ \\
\hline
\end{tabular}

\subsection{Naturally occurring cyclic peptides}

As a proof of concept, purified natural products $\mathbf{4}$ and $\mathbf{5}$ were obtained from an Australian collection of the seasquirt Lissoclinum patella. These natural products were subjected to HPLC-ICPMS/ESMS. The observed peaks for each sample in both positive mode ES-MS and ICP-MS were at the same retention time (tR) (Figure 2). Quantification of compound 4 [777 $\left.(\mathrm{M}+\mathrm{H})^{+}\right]$ with tR of $23.2 \mathrm{~min}$ (Figure $2 \mathrm{~A}$ ) revealed that the total solid mass of compound 4 in the analysed sample was between 29.0 to 30.8 $\%$ (Table 3). Compound $5\left[757(\mathrm{M}+\mathrm{H})^{+}\right]$with a tR of $24.3 \mathrm{~min}$ (Figure 2B) had between 84 and $89 \%$ total solid in the analysed sample (Table 3), using the developed method for quantification with compounds $\mathbf{1}$ or $\mathbf{2}$ as standard.
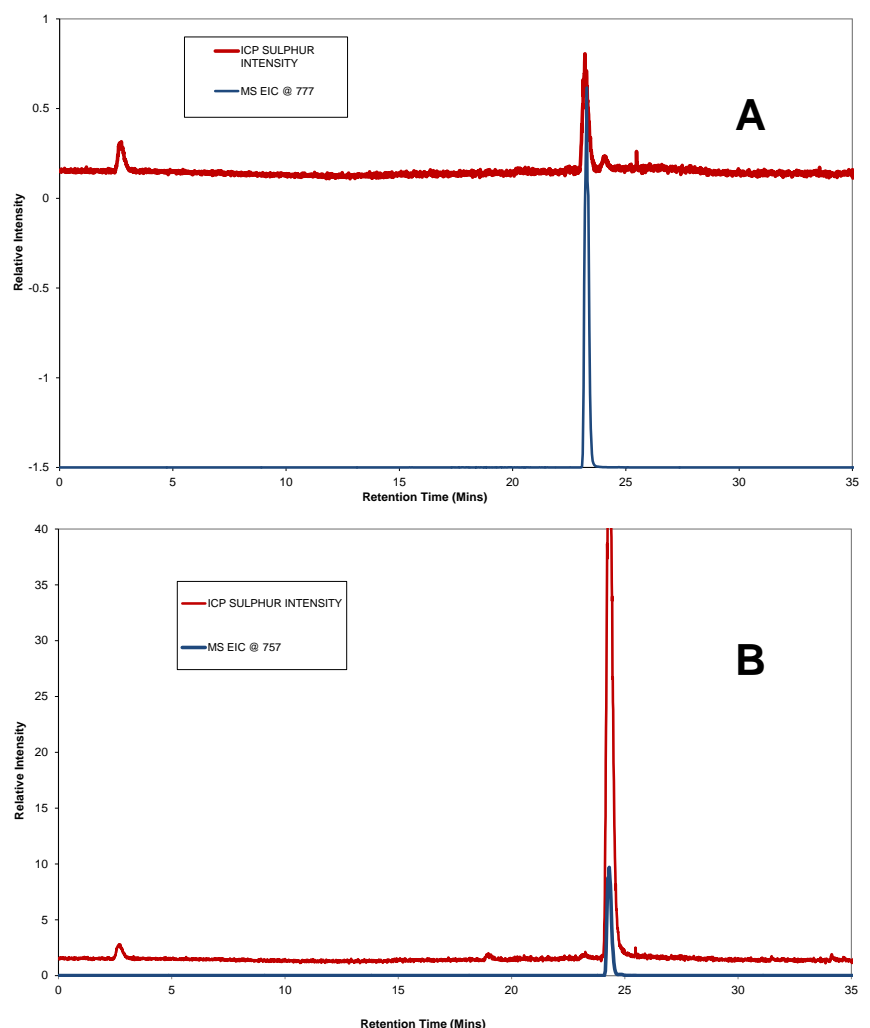

Figure 2: Separation of compound 4 and 5 containing solids and detection by ICPMS (red) and ESMS (blue), A) ICP-MS and extracted ion count (EIC) chromatograms of compound 4, B) ICP-MS and extracted ion count (EIC) chromatograms of compound $\mathbf{5}$.

\subsection{Biosynthetic peptides}

For HPLC-ICP-MS quantification, interferences were efficiently removed in the ICP-MS/MS with selection of dual $\mathrm{m} / \mathrm{z}$, 
for sulfur quantification, by measuring $\mathrm{S}, \mathrm{m} / \mathrm{z}, 32$ and 34 were obtained as ${ }^{32} \mathrm{~S}^{16} \mathrm{O}^{+}$and ${ }^{34} \mathrm{~S}^{16} \mathrm{O}^{+}$preventing $\mathrm{m} / \mathrm{z} \quad 48$ and 50 interferences ${ }^{66}$. Cyclic peptides 6-10 were extracted from chemoenzymatic reaction mixtures using SPE and subsequently identified and quantified by HPLC-ICPMS/ESMS. Solutions of samples $\mathbf{3}$ to $\mathbf{1 0}$ for species quantification were injected in triplicate and results are given as mean \pm SD except $\mathbf{8}$ and $\mathbf{9}$ (Table 3 ). These samples showed the presence of the respective peptides at different tRs (Figure S1-S5i in Supporting Information) the sulfur peak areas at each tRs for each compound was used for their individual quantification. Quantification results of the samples revealed that compound 6 and 7 contained $39.5 \%$ and $3.60 \%$, of the desired peptides respectively, while compound $\mathbf{8}$ contributed $75.8 \%$ to the analysed fraction, $5.0 \%$ of compound 9 was present in the analysed sample and compound $\mathbf{1 0}$ contained $11.5 \%$ of the peptide. RP-SPE method is useful for desalting and fractionation for compound before quantification, however data show that the estimated weight of samples was influenced by significant amounts of non-targeted compounds (data not shown) may be the reason for observed low concentrations for $\mathbf{6 , 7 , 9}$ and 10 after quantification, compared to the data obtained for $\mathbf{8}$, which was purified by HPLC. Recent studies by Møller et $\mathrm{al}^{67}$ for peptides in human plasma and Hermann et al. ${ }^{68}$ report for S-containing proteins shows the applicability of this method for accurate quantification of peptides.

Table 3: Theoretical concentration of samples, average amount of compounds recovered after quantification by sulfur for compounds $4, \mathbf{5}, \mathbf{6}, \mathbf{7}, \mathbf{8}, 9$ and 10 in $\mu \mathrm{g} / \mathrm{m}, \%$ compound recovery and purification methods.

\begin{tabular}{ccccc}
\hline Sample & $\begin{array}{c}\text { Theoretical } \\
\text { concentration } \\
(\boldsymbol{\mu g}\end{array}$ & $\begin{array}{c}\text { Average } \\
\text { compound } \\
\text { recovery } \boldsymbol{\mu g} \\
\text { compound/mL) } \\
\text { compound/mL }\end{array}$ & $\begin{array}{c}\text { \% } \\
\text { compound } \\
\text { recovery }\end{array}$ & $\begin{array}{c}\text { Purification } \\
\text { method }\end{array}$ \\
\hline $\mathbf{4 a}$ & 97.80 & $28.40 \pm 0.725$ & 29.70 & HPLC \\
$\mathbf{4 b}$ & 49.41 & $15.22 \pm 0.4650$ & 30.80 & HPLC \\
$\mathbf{5 a}$ & 135.6 & $115.0 \pm 1.991$ & 84.80 & HPLC \\
$\mathbf{5 b}$ & 41.70 & $37.13 \pm 1.112$ & 89.00 & HPLC \\
$\mathbf{6}$ & 899.4 & $355.0 \pm 3.098$ & 39.50 & SPE \\
$\mathbf{7}$ & 1400 & $50.33 \pm 4.752$ & 3.60 & SPE \\
$\mathbf{8}$ & 250.0 & 189.4 & 75.80 & HPLC \\
$\mathbf{9}$ & 987.5 & 49.78 & 5.00 & SPE \\
$\mathbf{1 0}$ & 1228 & $141.6 \pm 17.36$ & 11.50 & SPE
\end{tabular}

$\mathrm{a}$ and $\mathrm{b}$ are different concentrations for each sample.

\subsection{Comparison of Extraction Methods}

Quantification of samples obtained using various extraction methods for compound $\mathbf{1 0}$ revealed that reverse phase solid phase extraction RP-SPE gave optimum compound recovery and purity (Table 4). The protein concentrator and crude sample showed more peaks at retention times before $5 \mathrm{~min}$ due to high concentration of inorganic sulfate (Figure S7). This confirms the need for SPE in sample preparation of target compounds/ analytes ${ }^{69,70}$ as it increases the recovery of the compounds by removing the salts from the reaction buffer by selective isolation/fractionation of the cyclic peptides from the reaction mixture. This is consistent with work carried out by Loroch et al. using RP-SPE for phosphopeptide fractionation ${ }^{71}$. The protein concentrator fractions also showed the presence of other nonidentified sulfur containing compounds, which eluted through the filter with the compound of interest as the filter does not selectively isolate the apolar cyclic peptides from the more polar linear peptides, in contrast to the SPE process, hence reducing the percentage purity of the extract. We also observed that the $70 \AA$ SPE cartridge with a smaller pore size had a higher sample yield for our compounds in comparison to the $125 \AA$ SPE cartridge.

Table 4: Sample total dry weight, percentage purity and yield for each extraction method applied to compound $\mathbf{1 0}$ based on enrichment factor.

\begin{tabular}{|c|c|c|c|c|}
\hline Sample & $\begin{array}{c}\text { Sample } \\
\text { total dry } \\
\text { weight } \\
\text { (mg) }\end{array}$ & $\begin{array}{c}\text { Ratio of } \\
\text { compound/total } \\
\text { solid }\end{array}$ & $\%$ purity & $\begin{array}{c}\% \\
\text { compound } \\
\text { recovery }\end{array}$ \\
\hline Crude & 0.30 & 0.13 & $0.046 \pm 0.0072$ & \\
\hline SPE_125Å & 0.031 & 0.082 & $8.5 \pm 2.5$ & 10 \\
\hline SPE_70Å & 0.059 & 0.099 & $14 \pm 3.2$ & 19 \\
\hline Supernatant & 0.054 & 0.12 & $1.8 \pm 0.21$ & 18 \\
\hline Filtrate & 0.18 & 0.18 & $0.28 \pm 0.15$ & 61 \\
\hline
\end{tabular}

\subsection{Verification of quantification by NMR}

Compound 11 was used as an external reference material for calculating the ERETIC concentration of cyclic peptides (Table 5). Validation of this method for our system was achieved by comparing the calculated ERETIC concentration to that obtained by UV-absorbance at $280 \mathrm{~nm}$. A $500 \mu \mathrm{L}$ DMSO-d6 solution of $\mathbf{1 2}$ gave a theoretical concentration of $13 \mathrm{mM}$, equating to $5.1 \mathrm{mg}$ of $\mathbf{1 2}$ by UV. A qNMR spectrum of $\mathbf{1 1}$ was recorded and one of the benzyl-hydrogen peaks was integrated, set to $10 \mathrm{mM}$ and used for the ERETIC reference. Compound 12 was diluted to $600 \mu \mathrm{L}$ and qNMR spectrum was recorded. The distinct indole nitrogen peak was integrated, and its value compared to that of the ERETIC reference which gave a concentration of $13 \mathrm{mM}$, which corresponded to a total of $5.1 \mathrm{mg}$ of $\mathbf{1 2}$ (see Figure S7 for 1H NMR spectra). The total solid amount of $\mathbf{1 2}$ determined via UV absorbance and ERETIC quantification were with 5.06 and 5.08 mg respectively similar, thus showing that qNMR can be used to accurately determine the total solid in a purified cyclic peptide.

\subsection{Peptide Quantification by NMR}

Quantification of the naturally occurring peptides 4 and 5 (Table 5 and Figure S8 and S10) showed that compound 4 was $99 \%$ pure and compound $\mathbf{5}$ was $75 \%$ pure. The synthetic peptides subsequently quantified (Table 5 and Figure S11 to S14) showed that compound $\mathbf{1 3}$ contained of $21 \%$ of analysed sample, compound $\mathbf{1 4}$ contained $34 \%$ of the peptide while $\mathbf{1 5}$ and $\mathbf{1 6}$ contained $19 \%$ and $33 \%$ of the total solid of the analysed samples respectively. Given the high purity of compounds 13-16 we suggest that the low percentage of compound per total mass of powder can be attributed to significant retention of water during the freeze-drying process, which is supported by a large water peak $(\sim 3.3 \mathrm{ppm})$ in the NMR spectra (Figure S11-14) similar to the finding of Frank et al. ${ }^{72}$ analytical data presented shows that the actual quantity compounds were under estimated in the preparation of the stock solution.

Table 5: Weighed mass sample, concentration of compound and $\%$ compound obtained after qNMR quantification with their respective unit.

\begin{tabular}{cccc}
\hline Sample & $\begin{array}{c}\text { Weighed mass } \\
\text { of sample (mg) }\end{array}$ & $\begin{array}{c}\text { Experimental } \\
\text { mass of compound } \\
(\mathbf{m g})\end{array}$ & $\begin{array}{c}\% \\
\text { compound } \\
\text { recovery }\end{array}$ \\
\hline $\mathbf{4}$ & 5.70 & 5.67 & 99 \\
$\mathbf{5}$ & 8.10 & 6.05 & 75 \\
\hline
\end{tabular}




\begin{tabular}{llll}
\hline $\mathbf{1 3}$ & 1.50 & 0.31 & 21 \\
$\mathbf{1 4}$ & 4.97 & 1.69 & 34 \\
$\mathbf{1 5}$ & 1.60 & 0.30 & 19 \\
$\mathbf{1 6}$ & 5.40 & 0.54 & 33 \\
\hline
\end{tabular}

\section{Conclusion}

The samples batch containing $\mathbf{4}$ and $\mathbf{5}$ for the respective ICPMS and qNMR quantification were different. A low compound recovery for $\mathbf{4}$ in the ICPMS quantification compared to the NMR method was attributed to the presence of other unidentified compound(s) which added to the weight of the purified compound used for analysis; assuming that ionization efficiency was equal, on calculation of the extracted ion peak area with the $m / z$ for 4 used for each quantification method, the ICPMS sample had only $48 \%$ while the NMR sample had $87 \%$ of the compound mass. This may be the reason for the difference in quantification observed.

Accurate quantification of natural and non-natural modified cyclic peptides at various stages of purification by HPLC-ICPMS/ESMS and ${ }^{1} \mathrm{H}$ qNMR spectroscopic without the use of authentic standards is possible using these methods. Whereas the ICPMS method would be suitable for very small sample sizes with low purity and compounds containing a target element, the NMR method requires larger sample size and higher purity. Our data shows that these quantification methods can be applied to new compounds without authentic standards as they are not species specific but rely on elemental constitution of each compound. Application of these methods is possible for non-cyclic peptides as we were able to identify other organic and inorganic sulfur species using HPLCICPMS/ESMS. These methods also eliminate the drawbacks associated with quantification by only HPLC, UV or ESMS and polyatomic spectral interference associated with ICPMS sulfur quantification. Data obtained also show that sulfur quantification can be used to measure the purity of peptides and product yield using different extraction methods accurately from microgram to milligram quantity. ERETIC based proton qNMR can be used to quantify peptides in the presence or absence of heteroatoms.

\section{Experimental}

\subsection{Materials / methods}

\subsubsection{Sample}

Samples used for this work, listed in Table 1 include azole containing cyclic peptides isolated from Lissoclinum patella sourced from Davies Reef (the Great Barrier Reef), Australia, from a collection made in 2006, and analogues synthesised using recombinant biosynthetic enzymes using the method previously reported in Houssen et al. ${ }^{61}$

\subsubsection{Reagents and chemicals}

Milli-Q water (18 M $\Omega \mathrm{cm}$, Millipore, Germany) was used throughout the experiments. HPLC-solvents of highest purity available (methanol, acetonitrile and trifluoroacetic acid) were obtained from Sigma Aldrich (UK), whereas formic acid (>95\% reagent grade) was obtained from Fluka, UK. Nitric acid (69\%, p.a.) and hydrogen peroxide (30\%, trace select) were obtained from Fisher (UK) and DMSO-d6 (99.8\% purity manufactured by Cambridge Isotope Laboratories, USA). Cysteine $\mathbf{1}$ and $\mathrm{N}$ Acetylcysteine $\mathbf{2}$ used as sulfur standards were obtained from
Sigma (UK) and anthranilic acid $\mathbf{1 1}$ used as ERETIC standard was $>99.5 \%$ purity from Sigma-Aldrich, UK. Sulfur standard (1g/L) for total sulfur determination, rhodium and gallium $(1 \mathrm{~g} / \mathrm{L})$ were obtained from High-Purity Standards (USA). Certified reference materials for total sulfur determination were RM8415 (Whole egg powder, NIST, USA), BCR-062 (olive leaves, IRMM Geel) and Seronorm Trace elements in urine blank (Sero, Norway) and the in-house material methylthioninium chloride $\mathbf{3}$.

\subsubsection{Standards for ICPMS}

Standards for total sulfur determination were prepared in $2 \%$ (v/v) nitric acid. Sulfur standards $\mathbf{1}$ and $\mathbf{2}$ for HPLC were prepared freshly each day by dissolution in water with a concentration range between 5 and $100 \mathrm{mg} \mathrm{S} / \mathrm{kg}$.

\subsubsection{Microwave digestion for total $S$}

For total sulfur determination in RM8415 and BCR-062 both materials were digested using an open microwave system (MARS5, CEM, USA) with $2 \mathrm{~mL}$ nitric acid and $1 \mathrm{~mL}$ hydrogen peroxide for $30 \mathrm{~min}$ at $95{ }^{\circ} \mathrm{C}$. After cooling the samples were diluted with water to $2 \%$ (v/v) nitric acid. Seronorm urine and compound 3 (dissolved in water) were diluted using $2 \%(\mathrm{v} / \mathrm{v})$ nitric acid before measurement. The HPLC standards were also acidified with nitric acid (final concentration $2 \% \mathrm{v} / \mathrm{v}$ ) for verification of sulphur concentration.

\subsubsection{Solid Phase Extraction (SPE)}

Two types of SPE cartridges with silica as the sorbent were used to extract the peptides from protein mixtures using a vacuum extraction manifold (Phenomenex Strata $1 \mathrm{~g} \mathrm{C} 8,55 \mu \mathrm{m} 70 \AA$ and Waters Sep - Pak $1 \mathrm{~g} \mathrm{C} 8,37-55 \mu \mathrm{m} 125 \AA$ A). Each cartridge was conditioned with 5 column volumes $(\mathrm{CV})$ of methanol and $5 \mathrm{CV}$ of water after which the sample was loaded, washed with equal volume of water and subsequently eluted with $10 \mathrm{CV}$ of $50: 50 \mathrm{v} / \mathrm{v}$ water: methanol, $10 \mathrm{CV}$ of $100 \%$ methanol, $10 \mathrm{CV}$ of $100 \%$ acetonitrile and finally with $10 \mathrm{CV}$ of $0.05 \%$ trifluoroacetic acid in acetonitrile. The methanol and acetonitrile fractions were combined and concentrated under a stream of nitrogen. Residual dry sample was then weighed and reconstituted with methanol before use. Phenomenex Strata cartridges were used for extractions for all the samples studied while Waters Sep - Pak was used only for comparison of extraction method for compound $\mathbf{1 0 .}$

\subsubsection{Extraction Methods}

An aliquot of compound $\mathbf{1 0}$ enzymatic reaction mixture was divided into 12 vials containing $3.2 \mathrm{~mL}$ each, to allow triplicate measurements of each sample treatment method. The first set of three sample aliquots were extracted using Phenomenex strata $1 \mathrm{~g}$; $70 \AA$ C8 SPE, the methanol and acetonitrile eluates were then combined, concentrated, weighed and reconstituted in methanol for analysis, using the same treatment, the next set of samples was extracted using Waters $1 \mathrm{~g} ; 125 \AA$ C8 SPE column. The third set sample aliquots were transferred into $30 \mathrm{~mL}$ protein filters (protein concentrator MWCO 10,000 from GE Healthcare) and centrifuged at 2000 revolutions per minute (rpm) at $4{ }^{\circ} \mathrm{C}$ for $40 \mathrm{mins}$, the 
resulting filtrate was transferred into pre-weighed glass vials and the supernatants were transferred into $2 \mathrm{~mL}$ protein filters, and centrifuged for $30 \mathrm{mins}$ at $2000 \mathrm{rpm}$ the resulting filtrate was transferred into the initial filtrate, frozen and then freeze dried before re-weighing. The samples were then dissolved in Milli-Q water for analysis, the supernatants obtained after filtration using the $2 \mathrm{~mL}$ protein filter was transferred into a separate pre-weighed glass vials, frozen and then freeze dried before reweighing. This was then reconstituted in Milli-Q water. The last set of $3.2 \mathrm{~mL}$ sample aliquot crude sample was put in pre-weighed vials, frozen and freeze dried; sample weight was obtained before dissolving in Milli-Q water for analysis.

\subsection{7. ${ }^{1} H$ NMR Quantification}

Pure (95\%) $12(5.6 \mathrm{mg})$ of was dissolved in $500 \mu \mathrm{L}$ DMSOd6. The concentration of $\mathbf{1 2}$ in solution was determined first by $\mathrm{A}_{280}$ using a theoretical extinction coefficient of $5500 \mathrm{M}^{-1} \mathrm{~cm}^{-1}$ as calculated by ExPASy ProtParam. $\mathrm{A}_{280}$ measurements were performed on a NanoDrop ND-1000 spectrophotometer, which returned a concentration of $13 \mathrm{mM}$, equating to $5.1 \mathrm{mg}$ of product. The solution was diluted to $600 \mu \mathrm{L}$ and transferred to an NMR tube for qNMR and the spectrum recorded. A $1 \mathrm{M}$ solution of $\mathbf{1 1}$ was prepared in DMSO and subsequently diluted to $10 \mathrm{mM}$ using DMSO- $d_{6}$ before obtaining the qNMR spectrum. From this spectrum one of the well-defined and isolated benzyl-hydrogen peaks was integrated and set to $10 \mathrm{mM}$ as an ERETIC reference. The concentration of $\mathbf{1 2}$ was calculated by integrating the welldefined and isolated indole nitrogen peak and comparing the value with that of the ERETIC reference. Synthetic peptides 13-16 were quantified using the same procedure, data were analysed using TopSpin software (Bruker).

The dry mass of $\mathbf{4}$ and $\mathbf{5}$ weighed and dissolved in $800 \mu \mathrm{L}$ of DMSO- $d_{6}, 99 \mathrm{mM}$ stock solution of 11 in DMSO- $d_{6}$ was prepared from which $50 \mathrm{mM}$ and $20 \mathrm{mM}$ were made up. Proton NMR was acquired for the standards and samples sequentially on the same day using $5 \mathrm{~mm}$ tubes. Data was analysed using qNMR on MestReNova software for compound quantification.

\subsection{Instrumentation/Methods}

\subsubsection{ICPMS (total sulphur determination)}

An Agilent 8800 (Agilent Technologies, USA) was used for total sulfur determination. The instrument was used in MS/MSmode using oxygen as reaction gas. The general instrument parameters were optimized for robust plasma conditions using Nicones. Sulfur was measured in mass-shift mode on $\mathrm{m} / z, 49\left({ }^{33} \mathrm{~S}\right.$-> $\left.{ }^{33} \mathrm{~S}^{16} \mathrm{O}\right)$ and $\mathrm{m} / \mathrm{z} 50\left({ }^{34} \mathrm{~S}->{ }^{34} \mathrm{~S}{ }^{16} \mathrm{O}\right)$. Gallium $(10 \mu \mathrm{g} / \mathrm{kg})$ was used as internal standard.

\subsubsection{Preparative HPLC Separation}

Reverse phase liquid chromatographic separation was used for sample separation using an Agilent 1260 infinity HPLC system; each sample separation gradient was developed depending on the best separation chromatogram observed using a UV detector. Chromatographic methods are as shown in Table 6, methods A and $\mathrm{B}$ were used for the purification of Lissoclinum patella extract to obtain 4 and $\mathbf{5}$, while methods $\mathrm{C}$ and D were analytical methods used for HPLC-ICPMS/ESMS.
Table 6: LC separation gradient for the purification of compound $\mathbf{7}$ and $\mathbf{8}$ (method $\mathrm{A}$ and $\mathrm{B})$ and methods $\mathrm{C}$ and $\mathrm{D}$ used for quantification.

\begin{tabular}{|c|c|c|c|c|}
\hline $\begin{array}{l}\text { Instrument } \\
\text { Parameter } \\
\end{array}$ & $\begin{array}{c}\text { Method A } \\
\text { preparative }\end{array}$ & $\begin{array}{c}\text { Method B } \\
\text { preparative }\end{array}$ & $\begin{array}{l}\text { Method C } \\
\text { Analytical } \\
\end{array}$ & $\begin{array}{l}\text { Method D } \\
\text { Analytical } \\
\end{array}$ \\
\hline Column & $\begin{array}{l}\text { Sunfire C18 } \\
10 \mu \mathrm{m} 10 \mathrm{x} \\
250 \mathrm{~mm} \mathrm{D}\end{array}$ & $\begin{array}{c}\text { YMC-Pack } \\
\text { pro C4, } 3 \\
\mu \mathrm{m} 12 \mathrm{~nm}, \\
150 \times 4.6 \\
\mathrm{~mm} \mathrm{D}\end{array}$ & $\begin{array}{c}\text { Agilent } \\
\text { XBD- } \\
\text { Eclipse C18, } \\
4.6 \text { x } 150 \\
\text { mm D } \\
\text { Poresize } 5 \\
\mu \mathrm{m}\end{array}$ & $\begin{array}{c}\text { YMC-Pack } \\
\text { Pro C4 } 150 \\
\text { x4.6 mmD, } \\
\text { S-3 } \mu \mathrm{m}\end{array}$ \\
\hline Flowrate & $1.5 \mathrm{~mL} / \mathrm{min}$ & $1.0 \mathrm{~mL} / \mathrm{min}$ & $0.9 \mathrm{~mL} / \mathrm{min}$ & $0.9 \mathrm{~mL} / \mathrm{min}$ \\
\hline $\begin{array}{l}\text { Injection } \\
\text { Volume }\end{array}$ & $200 \mu \mathrm{L}$ & $100 \mu \mathrm{L}$ & $20 \mu \mathrm{L}$ & $20 \mu \mathrm{L}$ \\
\hline $\begin{array}{l}\text { Column } \\
\text { temperature }\end{array}$ & $30^{\circ} \mathrm{C}$ & $30^{\circ} \mathrm{C}$ & $35^{\circ} \mathrm{C}$ & $35^{\circ} \mathrm{C}$ \\
\hline Solvent A & milliQ water & milliQ water & $\begin{array}{c}0.1 \%(\mathrm{v} / \mathrm{v}) \\
\text { Formic acid } \\
\text { in water }\end{array}$ & $\begin{array}{c}0.1 \%(\mathrm{v} / \mathrm{v}) \\
\text { Formic acid } \\
\text { in water }\end{array}$ \\
\hline Solvent B & Acetonitrile & Acetonitrile & $\begin{array}{l}0.1 \%(\mathrm{v} / \mathrm{v}) \\
\text { Formic acid } \\
\text { in Methanol }\end{array}$ & $\begin{array}{l}0.1 \%(\mathrm{v} / \mathrm{v}) \\
\text { Formic acid } \\
\text { in Methanol }\end{array}$ \\
\hline Gradient & $\begin{array}{c}0-20 \mathrm{~min}: \\
0-100 \% \mathrm{~B} \\
20-32 \mathrm{~min} \\
100 \% \mathrm{~B}\end{array}$ & $\begin{array}{c}0-25 \mathrm{~min}: \\
0-100 \% \mathrm{~B} \\
20-32 \mathrm{~min} \\
100 \% \mathrm{~B}\end{array}$ & $\begin{array}{c}0-25 \mathrm{~min}: \\
0-100 \% \mathrm{~B} \\
25-35 \mathrm{~min} \\
100 \% \mathrm{~B}\end{array}$ & $\begin{array}{c}0-20 \mathrm{~min}: \\
10-100 \% \\
\mathrm{~B} \\
20-25 \mathrm{~min} \\
100 \% \mathrm{~B}\end{array}$ \\
\hline
\end{tabular}

\subsubsection{HPLC-ICPMS / ESMS}

An Agilent 1100 HPLC system consisting of cooled autosampler, quaternary pump and column thermostat was used for the separation of the samples. The autosampler was cooled to $4{ }^{\circ} \mathrm{C}$, whereas the column was held at $35{ }^{\circ} \mathrm{C}$. A sample volume of $20 \mu \mathrm{L}$ was used throughout. The columns and separation conditions used are summarized in Table 6 methods $C$ and D. The column effluent was split 1:4 using a QuickSplit Post-Column Flow splitter (ASI, USA), with 1 part of the effluent infused into the ICPMS and 3 parts into the ES-MS.

The ICPMS used was an 8800 Agilent system (Agilent Technologies, USA). The instrument was used in organic mode including Pt-cones, small ID torch and PFA-micronebulizer. Further instrument parameters are given in Table 7; the instrument was optimized daily for highest sensitivity under robust plasma conditions. Sulfur was determined using oxygen in the reaction cell in MS/MS mode using the mass-shifts of $m / z, 48\left({ }^{32} \mathrm{~S}->{ }^{32} \mathrm{~S}^{16} \mathrm{O}\right)$ and $m / z, 50\left({ }^{34} \mathrm{~S} 34->{ }^{34} \mathrm{~S}^{16} \mathrm{O}\right)$. Rhodium $(10 \mu \mathrm{g} / \mathrm{L})$ in $1 \%$ nitric acid was used as continuous internal standard. To correct for intensity shifts due to the methanol gradient a blank run using a continuous internal standard containing sulfur and rhodium as described in Amayo et $a l^{65}$ was used for correction.

An LTQ-Orbitrap Discovery from Thermo Scientific, UK was the ESMS system used for molecular identification. The splitter outlet (3 parts) was directly connected to the ES-inlet. The instrument was optimized daily for highest sensitivity and mass accuracy in positive mode. Further instrument parameters can be found in Table 7. 
Table 7: Instrumentation parameter for ICPMS and ESMS optimized for peptide quantification

\begin{tabular}{cc}
\hline $\begin{array}{c}\text { Instruments } \\
\text { Parameter }\end{array}$ & Value \\
ICP-MS & Agilent 8800 \\
Mode & Organic (Pt- cones, organic \\
torch, PFA- micronebulizer) & $1600 \mathrm{~W}$ \\
HF & Microflow \\
Nebulizer- type & $0.91 \mathrm{~L} / \mathrm{min}$ \\
Nebulizer gas & $6 \%$ oxygen $\left(80: 20\right.$ Ar: $\left.\mathrm{O}_{2}\right)$ \\
Optional gas & $0.98 \mathrm{Lmin}$ \\
Plasma gas & $15.5 \mathrm{~L} / \mathrm{min}$ \\
Coolant gas & $\mathrm{O}_{2}$ \\
Reaction cell gas & $0.3 \mathrm{~mL} / \mathrm{min}$ \\
Reaction cell gas flow & \\
& LTQ Orbitrap Discovery \\
ESI - MS: & (Thermo Scientific) \\
& Positive \\
Mode & 30,000 \\
Resolution & automatic \\
MSMS mode & $4.5 \mathrm{KV}$ \\
Ionspray voltage &
\end{tabular}

\subsection{4. $N M R$}

NMR experiments were performed at $25{ }^{\circ} \mathrm{C}$ for $\mathbf{4}$ and $\mathbf{5}$ in a Bruker Ascend 400MHz NMR machine with a Z116098_0444 (PA BBO 400S1 BBF-H-D-05 Z SP) probe while Bruker DRX500 spectrometer equipped with a $5 \mathrm{~mm}$ TXIz probe was used for 1316. Data acquisition for all compounds was done at 64 scans, 10.00 compensate, $90^{\circ}$ pulse and $30 \mathrm{sec}$ Delay.

\section{Acknowledgments}

MJ, JHN, WEH, LT gratefully acknowledge support from the the Leverhulme Trust (RPG 2012-504). JT and AR were funded by EU-FP7 project 'PharmaSea' (contract 312184) and ARM and GM were funded by Scottish Enterprise High Growth Spinout Programme PS7305CA38.

\section{References and Notes}

1. Barnidge, D. R.; Dratz, E. A.; Martin, T.; Bonilla, L. E.; Moran, L. B. Anal. Chem. 2003, 445-451.

2. Zhu, L.; Tamvakopoulos, C.; Xie, D.; Dragovic, J.; Shen, X.; Fenyk- Melody, J. E.; Schmidt, K.; Bagchi, A.; Griffin, P. R.; Thornberry, N. A.; Roy, R. S. J. Biol. Chem 2003, 278, 2241822423.

3. Weckwerth, W.; Willmitzer, L.; Fiehn, O. Rapid Commun. Mass Spectrom. 2000, 1677-1681.

4. John, H.; Walden, M.; Schafer, S.; Genz, S.; Forssmann W. Anal. Bioanal. Chem 2004, 883-897.

5. Goltzman, D. Nat. Rev. Drug Discovery, 1, 784-796.

6. Douglas, S. A. Current Opin. Pharmacol. 2003, 159-167.

7. Hajee, C. A. J.; van Rhijn, H. A.; Lasaroms, J. J. P.; Keukens, H. J.; de Jong, J. Analyst 2001, 126, 1332-1338.

8. Stegehuis, D. S.; Tjaden, U. R.; van den Beld, C. M. B.; van der Greef, J. J Chromatogr. 1991, 549, 185-193.

9. Pauli, G. F.; Gödecke, T.; Jaki, B. U.; Lankin, D. C. J. Nat. Prod. 2012, 834-851.

10. Peffers, M. J.; Beynon, R. J.; Clegg, P. D. Int. J. Mol. Sci. 2013, 20658-20677.

11. Prange, A.; Pröfrock, D. J Anal. At. Spectrom. 2008, 23, 432-459.

12. Gerber, S. A.; Rush, J.; Stemman, O.; Kirschner, M. W.; Gygi, S. P. Proc. Natl. Acad. Sci. USA 2003, 100, 6940-6945.
13. Yi, E.C.; Li, X.J.; Cooke, K.; Lee, H.; Raught, B.; Page, A.; Aneliunas, V.; Hieter, P.; Goodlett, D.R.; Aebersold, R. Proteomics 2005, 5, 380-385.

14. Hansen, K.C.; Schmitt-Ulms, G.; Chalkley, R.J.; Hirsch, J.; Baldwin, M.A.; Burlingame, A.L. Mol. Cell. Proteomics 2003, 2 , 299-314.

15. Qu, J.; Straubinger, R. M. Rapid Commun. Mass Spectrom. 2005, 19, 2857-2864.

16. Rainczuk, A.; Condina, M; Pelzing, M.; Dolman, S.; Rao, J; Fairweather, N.; Jobling, T.; Stephens, A.N. J. Proteome Res. 2013, 12, 4074-4088.

17. Schmidt, A.; Kellermann, J.; Lottspeich, F. Proteomics 2005, 5, 415.

18. Lottspeich, F.; Kellermann, J. Methods Mol. Biol. 2011, 753, 5564.

19. Oda, Y.; Huang, K.; Cross, F.R.; Cowburn, D., Chait, B.T. Proc. Natl. Acad. Sci. USA 1999, 96, 6591-6596.

20. Blagoev, B.; Kratchmarova, I.; Ong, S.E.; Nielsen, M.; Foster, L.J.; Mann, M. Nat. Biotechnol. 2003, 21, 315-318.

21. Krüger, M.; Moser, M.; Ussar, S.; Thievessen, I.; Luber, C.A.; Forner, F.; Schmidt, S.; Zanivan, S.; Fässler, R.; Mann, M. Cell 2008, 134, 353-364.

22. Dayon, L.; Hainard, A.; Licker, V.; Turck, N.; Kuhn, K.; Hochstrasser, D.F.; Burkhard, P.R.; Sanchez, J. C. Anal. Chem. 2008, 80, 2921-2931.

23. Ting, L.; Rad, R.; Gygi, S.P.; Haas, W. Nat. Methods 2011, 8, 937-940.

24. Kettenbach, A.N.; Rush, J.; Gerber, S.A. Nat. Protoc. 2011, 6 , 175-186.

25. Prakash, A.; Tomazela, D.M.; Frewen, B.; Maclean, B.; Merrihew, G.; Peterman, S.; Maccoss, M.J. J. Proteome Res. 2009, 8, 2733 2739

26. He, Y.; Zhang, Y.; Wei, C.; Li, C.; Gao, Y.; Liu,R. Appl. Spec. Rev. 2014, 49, 6, 492-512.

27. Osama, C.; Diego, C.; John, M. J. Pharm. Biomed. Anal. 2015, $113,2-20$

28. Ahrends, R.; Pieper, S.; K€uhn, A.; Weisshoff, H.; Hamester, M.; Lindemann, T.; Scheler, C.; Lehmann, K.; Taubner, K.; Linscheid, M. W. Mol. Cell. Proteomics 2007, 6, 1907-1916.

29. Pereira-Navaza, A.; Ruiz-Encinar, J.; Sanz-Medel, A. Angew. Chem. Int. Ed. 2007, 46, 569-571.

30. Xu, M.; Yang, L. M.; Wang, Q. Q. J. Anal At Spectrom 2008, 23, 1545-1549.

31. Xu, M.; Yan, X. W.; Xie, Q. Q.; Yang, L. M.; Wang, Q. Q. Anal. Chem. 2010, 82, 1616-1620.

32. Theiner, S.; Kornauth, C.; Varbanov, H. P.; Galanski, M.; Schoonhoven, S. V.; Heffeter, P.; Berger, W.; Egger, A. E.; Keppler, B. K. Metallomics 2015, 7, 1256-1264.

33. Wind, M.; Wegener, A.; Eisenmenger, A.; Kellner, R.; Lehmann, W. D. Angew. Chem. Int. Ed. 2003, 42, 3425-3427.

34. Yan, X. W.; Yang, L. M.; Wang, Q. Q. Angew. Chem. Int. Ed. 2011, 50, 5130-5133.

35. Yan, X. W.; Luo, Y. C.; Zhang, Z. B.; Li, Z. X.; Luo, Q.; Yang, L. M.; Zhang, B.; Chen, H. F.; Bai, P. M.; Wang, Q. Q. Angew. Chem. Int. Ed. 2012, 51, 3358-3363.

36. El Balkhi, S.; Poupon, J.; Trocello, J. M.; Massicot, F.; Woimant, F.; Laprévote, O. Anal. Chem. 2010, 82, 6904-6910.

37. Suzuki, Y.; Nobusawa, A.; Furuta, N. Anal. Sci. 2014, 30, 551 559.

38. Bierla, K.; Bianga, J.; Ouerdane, L.; Szpunar, J.; Yiannikouris, A.; Lobinski, R. J. Proteomics 2013, 87, 26-39.

39. Wang, M.; Feng, W.; Lu, W.; Li, B.; Wang, B.; Zhu, Wang, Y.; Yuan, H.; Zhao, Y.; Chai, Z. Anal. Chem. 2007, 79, 9128-9134.

40. Bernstein, M. A.; Sýkora, S.; Peng, C.; Barba, A.; Cobas, C.; Anal. Chem. 2013, 85, 5778-5786.

41. Albers, M. J.; Butler, T. N.; Rahwa, I.; Bao, N.; Keshari, K. R.; Swanson, M. G.; Kurhanewicz, J. Magn. Reson. Med 2009, 61, 525-532.

42. Barding, G. A. Jr.; Salditos, R.; Larive, C. K. Anal. Bioanal Chem. 2012, 404, 1165-1179.

43. Akoka, S.; Barantin, L.; Trierweiler, M.; Anal. Chem. 1999, 71, 2554-2557.

44. Lane, S.; Boughtflower, B.; Mutton, I.; Paterson, C.; Farrant, D.; Taylor, N.; Blaxill, Z.; Carmody, C.; Borman, P. Anal. Chem. 2005, 77, 4354-4365.

45. Giordanetto, F.; Kihlberg, J. J. Med Chem. 2014, 278-295.

46. Arnison, P. G.; Bibb, M. J.; Bierbaum, G.; Bowers, A. A.; Bugni, T. S.; Bulaj, G.; Camarero, J. A.; Campopiano, D. J.; Challis GL, Clardy J, Cotter PD, Craik DJ, Dawson M, Dittmann E, Donadio 


\section{Tetrahedron}

S, Dorrestein PC, Entian KD, Fischbach MA, Garavelli JS, Göransson U, Gruber CW, Haft DH, Hemscheidt TK, Hertweck C, Hill C, Horswill AR, Jaspars M, Kelly WL, Klinman JP, Kuipers OP, Link AJ, Liu W, Marahiel MA, Mitchell DA, Moll GN, Moore BS, Müller R, Nair, S.K.; Nes, I. F.; Norris, G. E.; Olivera, B. M.; Onaka H.; Patchett, M. L.; Piel, J.; Reaney, M. J.; Rebuffat, S.; Ross, R. P.; Sahl, H. G.; Schmidt, E. W.; Selsted, M. E.; Severinov, K.; Shen, B.; Sivonen, K.; Smith, L.; Stein, T.; Süssmuth, R. D.; Tagg, J. R.; Tang, G. L.; et al. Nat Prod Rep 2013, 108-160.

47. Houssen, WE. \& Jaspars, M ChemBioChem 2010, 11, 1803-1815.

48. Goto, Y.; Ito, Y.; Kato, Y.; Tsunoda, S.; Suga, H. Chem. Biol. 2014, 788-774.

49. Drigger, E. M.; Hale, S. P.; Lee, J.; Terrett, N. K. Nat. Rev. Drug Discov. 2008, 608-624.

50. Longley, D. B.; Johnston, P. G. J. Pathol. 2005, 275-292.

51. Williams B.A., J. R. S. Cancer Lett. 1993, 71, 97-102.

52. Aller S.G, Yu J, Ward A, Weng Y,et al. Science 2009, 323, 17181721.

53. Long, P. F.; Dunlap, W. C.; Battershill, C. N.; Jaspars, M. ChemBioChem 2005, 6, 1760-1765.

54. Schmidt, E. W.; Nelson, J. T.; Rasko, D. A.; Sudek, S.; Eisen, J. A.; Haygood, M. G.; Ravel, J. Proc Natl Acad Sci USA 2005, 102, 7315-7320.

55. Houssen, W. E.; Wright, S. H.; Kalverda, A. P.; Thompson, G. S.; Kelly, S. M.; Jaspars, M. ChemBioChem 2010, 11, 1867-1873.

56. Koehnke, J.; Bent, A. F.; Zollman, D.; Smith, K.; Houssen, W. E.; Zhu, X.; Mann, G.; Lebl, T.; Scharff, R.; Shirran, S.; Botting, C. H.; Jaspars, M.; Schwarz-Linek, U.; Naismith, J. H. Angew. Chem. Int. Ed. 2013, 52, 13991-13996.

57. Koehnke, J.; Bent, A. F.; Houssen, W. E.; Zollman, D.; Morawitz, F.; Shirran, S. L.; Vendome, J.; Nneoyiegbe, A. F.; Trembleau, L.; Botting, C. H.; et al. Nature Structural and Molecular Biology 2012, 19, 767-772.

58. Leikoski, N.; Liu, L.; Jokela, J.; Wahlsten, M.; Gugger, M.; Calteau, A.; Permi, P.; Kerfeld, C. A.; Sivonen, K.; Fewer, D. P. Chem. Biol. 2013, 1033-1043.

59. Donia, M. S.; Hathaway, B. J.; Sudek, S.; Haygood, M. G.; Rosovitz, M. J.; Ravel, J.; Schmidt, E. W. Nat. Chem. Biol. 2006, 2, 729-735.

60. Bent, A. F.; Koehnke, J.; Houssen, W. E.; Smith, M. C. M.; Jaspars, M.; Naismith, J. H. Acta Cryst. 2013, F69, 618-623.

61. Houssen, W. E.; Bent, A. F.; McEwan, A. R.; Pieiller, N.; Tabudravu, J.; Koehnke, J.; Mann, G.; Adaba, R. I.; Thomas, L.; Hawas, U. W.; Liu, H.; Schwarz-Linek, U.; Smith, M. C. M.; Naismith, J. H.; Jaspars, M. Angew. Chem. Int. Ed. 2014, 1-5.

62. Tianero, M. D.; Donia, M. S.; Young, T. S.; Schultz, P. G.; Schmidt, E. W. J. Am. Chem. Soc 2012, 134, 418-425.

63. McIntosh, J.A.; Donia, M. S.; Schmidt, E. W. J. Am. Chem. Soc. 2010, 132, 4089-4091.

64. McIntosh, J. A.; Schmidt, E. W. ChemBioChem. 2010, 11, 14131421.

65. Amayo, K. O.; Petursdottir, A.; Newcombe, C.; Gunnalaugsdottir, H.; Raab, A.; Krupp E.V. Feldmann, J. Anal. Chem. 2011, 83, 3589-3595.

66. Martínez-Sierra, J. G.; Galilea San Blas, O.; Marchante Gayón, J.M.; García Alonso, J.I. Spectrochim. Acta. 2015, 108, 35-52.

67. Møller, L.H.; Macharius, A.; Hansen, T. H.; Nielsen, H.M.; Cornett, C.; Østergaard, J.; Stürupa, S.; Gammelgaard, B. J. Anal. At. Spectrom. 2016, 31, 1877.

68. G. Hermann, G.; Moller, L. H.; Gammelgaard, B.; J. Hohlweg, J.; Mattanovich, D.; Hann, S.; Koellensperger, G. J. Anal. At. Spectrom. 2016, 31, 1830-1835.

69. Buszewski, B.; Szultka, M. Crit. Rev. Anal. Chem., 2012, 42:198213, 2012.

70. Rogeberg, M.; Malerod, H.; Hanne Roberg-Larsen, H.; Aass, C.; Wilson, S. R. J. Pharm. Biomed. Anal. 2014, 87, 120- 129.

71. Loroch, S.; Zahedi, R. P.; Sickmann, A. Anal. Chem. 2015, 87, 1596-1604.

72. Frank, O.; Kreissl, J.K.; Daschner, A.; Hofmann, T. J. Agric. Food Chem. 2014, 62, $2506-2515$. 